7. Child Lang. 40 (2013), 509. (C) Cambridge University Press 2013 doi:I0.1017/So305000913000044

E R R A T U M

\title{
Journal of Child Language, volume 39 contents list - ERRATUM
}

doi:Io.ror7/So3050009I200044X, Published by Cambridge University Press, Io October 2012

An article by Maria D. Vázquez et al entitled 'Four- and six-year-olds use pragmatic competence to guide word learning' was listed in the volume 39 contents list for 2012 as appearing on page 997. This listing was unfortunately incorrect and in fact the article appears in this volume (40.2) on page $29 \mathrm{I}$.

Cambridge University Press sincerely apologises for any confusion this may have caused.

\section{REFERENCE}

(2012). JCL volume 39 issue 5 Cover and Back matter. Fournal of Child Language, 39, pp bi-b8. 